\title{
The Toposequential Analysis and Cultivation of the Land Skills Misserghin Region (the Northern Margin of the Oran Great Sebkha-Algeria)
}

\author{
Mostafia Boughalem ${ }^{1, *}$, Kacem Moussa ${ }^{2}$, Mansour Zaagane ${ }^{3}$ \\ ${ }^{1}$ Laboratory of Applied Hydrology and Environment/DGRSDT, University Centre of Ain Temouchent, Algeria \\ ${ }^{2}$ Faculty of Science of the Earth El Menouar, University Oran, Algeria \\ ${ }^{3}$ Laboratory of Biological Systems and Geomatics, University of Mascara, (LRSBG), Algeria
}

Copyright $\mathrm{O} 2016$ by authors, all rights reserved. Authors agree that this article remains permanently open access under the terms of the Creative Commons Attribution License 4.0 International License

\begin{abstract}
Topo-sequential analysis based on data of: clay analysis, climate, vegetation, geology and geomorphology of soil. This allows identifying different types of soil in Misserghin area. Our results show the presence of three types of soil as following: (i) The Iron siallitic soils founded at the bottom of Murdjadjo Mountain. It corresponds to an agrological poor quality land. It is situated in a medium depth. These soils have one or more adverse characters that can be developed in a modest way; (ii) The Alluvial soils, which occupying the plain of Misserghin on a medium slopes, these corresponds to an agrological good quality land, (iii) The Saline sodic soils (or salino-sols) which are founded in the downstream part of the catchment area (in the proximity of the Sebkha) and they showed very poor agrological quality. The key recommendation in relation to the development of agriculture in the north of the Oran Great Sebkha, is the concentration of farming activities in the alluvial soils that have good agrological quality land where the slope is delivering an average vast plain like the Misserghin plain. This area served as a model of cultural aptitudes of studies based on a thin topo-sequential analysis.
\end{abstract}

Keywords Clays, Topo-sequential Analysis, Cultural Skills, Misserghin, the Northern Margin of the Great Sebkha of Oran, Western Algeria

\section{Introduction}

The study area is situated near Oran at $20 \mathrm{Km}$ in the South; it's limited in the north by the littoral Moutains, the south by the Oran Great Sebkha in the West by Melata plain. In the East the Habra plain, correspond to their easthern continuity. This area is located in the The Bas-Chelif basin, which is evolved during the Neogene period. The geological process area leaded the deposition of different sediments characterized by a diversity of facies with frequent side passages. The Miocene in its totality is characterized by marly sedimentation. The exception is made for the Messinian period which is marked by salt deposition. The aim of this study is to describe soil science of the northern margin of the Oran Great Sebkha, to show the different types of soil characterizing the area Misserghin from topo-sequential, geomorphological analysis and listed structures. It highlighted the relationship between the soil and the physical factors have gradually led; these factors are geological type tectonic, geomorphology, climate, drainage, vegetation and clay minerals.

\section{General Framework Geographical}

Neogene subtidal lands of western Algeria elongate parallel to the Mediterranean, from the Moroccan border to the west (near Algiers) [50], They are not very high compared to surrounding chains. The altitude of the borders of these basins can reach $600 \mathrm{~m}$. They extend over a hundred $\mathrm{km}$ and form a width of 20 to $25 \mathrm{Km}$. (Figure 1). The Neogene Bas Chelif Basin is part of the largest nearshore basins of the North Western Algeria. According to Thomas [52], this basin is divided into two parts:

In its eastern part, this basin is separated from the sea by the chain of Dahra, Beni Manacer, limited to the south by Ouarsenis Mountains.

In its western part, the northern edge includes Jebel Murdjadjo and Djebel Orousse while Mountains Tessala and Beni Chougrane form its southern boundary. The western part is in a well-limited area: In the north by the current shoreline; to the east by the western terminus of the Dahra and the Oued Mina; In the South by highlands (Monts de Saida, Daïa and Tlemcen) and on the west by OuedTafna. 


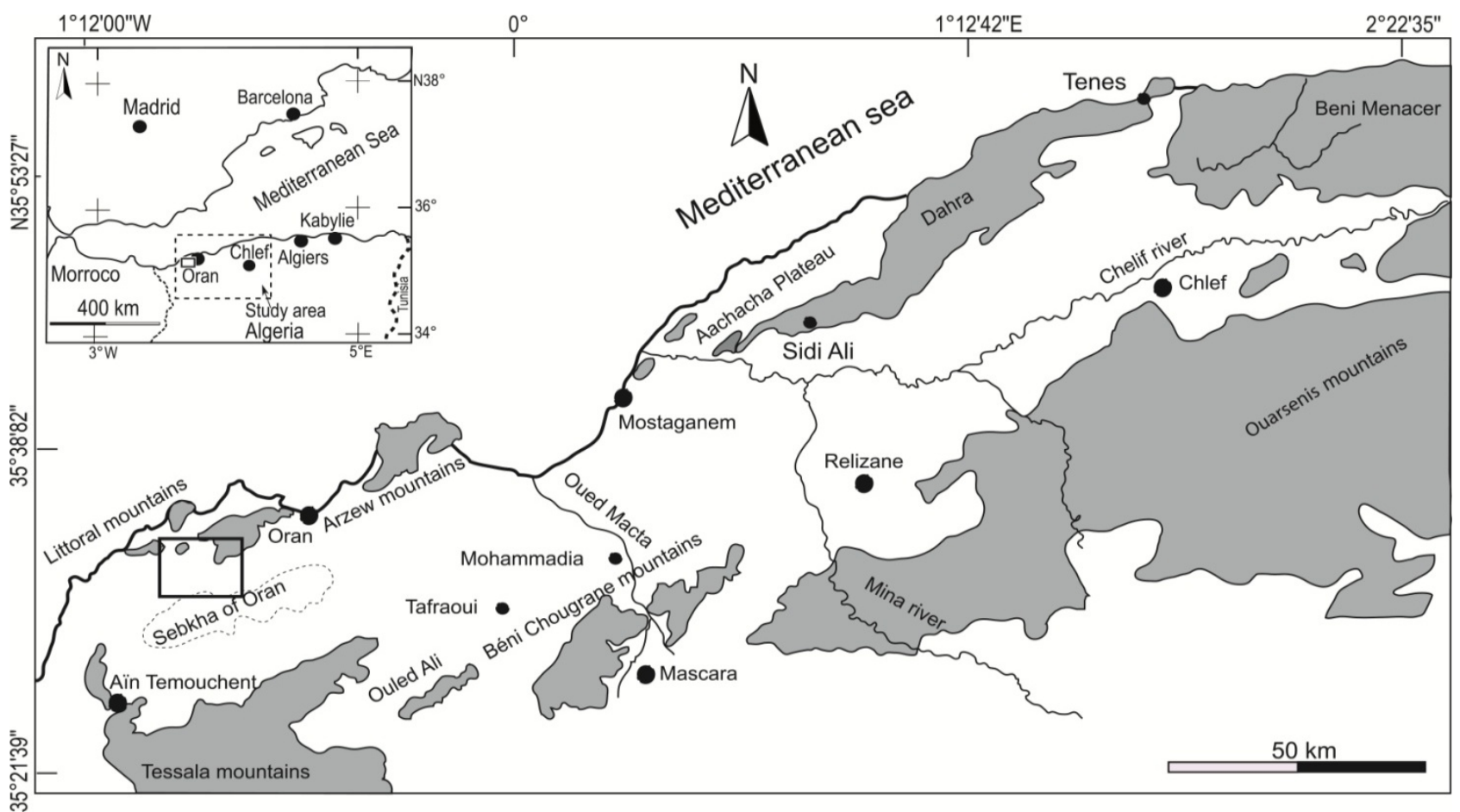

Figure 1. Location map of the study area (grey area show the geographic position of the Tellian chain of Algeria) [44]

\section{General Geological Setting (Figure 2)}

The filling of the basin took place throughout the Mio-Pliocene-Quaternary. The Lower Basin Chelif has originated in Miocene and evolved until the Quaternary. According to Perrodon [49], this basin developed after the major tectonic phase of Tellian field, is a late-orogenic intra-mountainous basin [49]. There remains and occupies much of the median furrow [48]. According to Thomas [52], sedimentation is controlled by tectonic phenomena syn-sedimentary. It belongs to a set of more or less independent diachronous sedimentary areas, which are superimposed on the Tello-Rifan orogeny after the introduction of non-native land. The basin has been the subject of several studies: (Delfaud et al, 1973) in [1] distinguishes a lower Miocene transgressive or ante-plies characterized by megasequencel and superior Miocene and post-plies characterized by mega-sequence 2 , subdivided into three sequences (2a 2b-2c).

Fenet [20] introduced the concept of post-Neogene aquifers within which there are three cycles. 1st cycle Miocene "post nappe" (MI): represented by thick clastic deposits. 2nd Miocene cycle "post-nappes" (IBD): independent of the first and transgresses the 3rd Pliocene cycle.

Perrodon [49] has involved the notion of sedimentary cycle. He divided the Neogene Miocene and Pliocene in two cycles. He distinguished undergraduate spotted two phases on the edges of the basin by a regression and transgression, separated by an unconformity. This is a Miocene upper side; the first is assimilated to Burdigalian, second in the Late Miocene. It characterizes the first as transgressive followed by a regression, the second is transgressive over the entire pelvis but in a progressive manner. Thomas [52] described the post- Miocene sedimentary aquifers as a cycle fifth order and subdivided into two fourth order sedimentary cycles (MII, MIII) that are in turn made up of order three courses. Continental sediments and other marine whose age is between the Tortonian and Burdigalian by the same author represent the first cycle (IBD). Detrital marl and evaporate sediments that begin at the upper Tortonian and continue during the Messinian represented the second cycle (MIII).

According to Gourinard [21] and Perrodon [49], the Oran coast is considered a geological feature that differentiates itself by geological and structural features very marked and is found in both mountainous regions and subsidence areas. According to Gourinard [22].The distribution of some Pliocene sediments of Oran coast shows that this horst suffered a replay at the boundary between the Miocene and the Pliocene, replay probably less important than the Quaternary.

The stratigraphy represented in the study area includes:

- The earth and synchro-nappes bedrock.

- The Miocene (First post- cycle table cloths, table cloths second post- cycle)

- The lower Pliocene and Pleistocene.

- The Quaternary (Middle Pleistocene, Holocene and Pleistocene). 


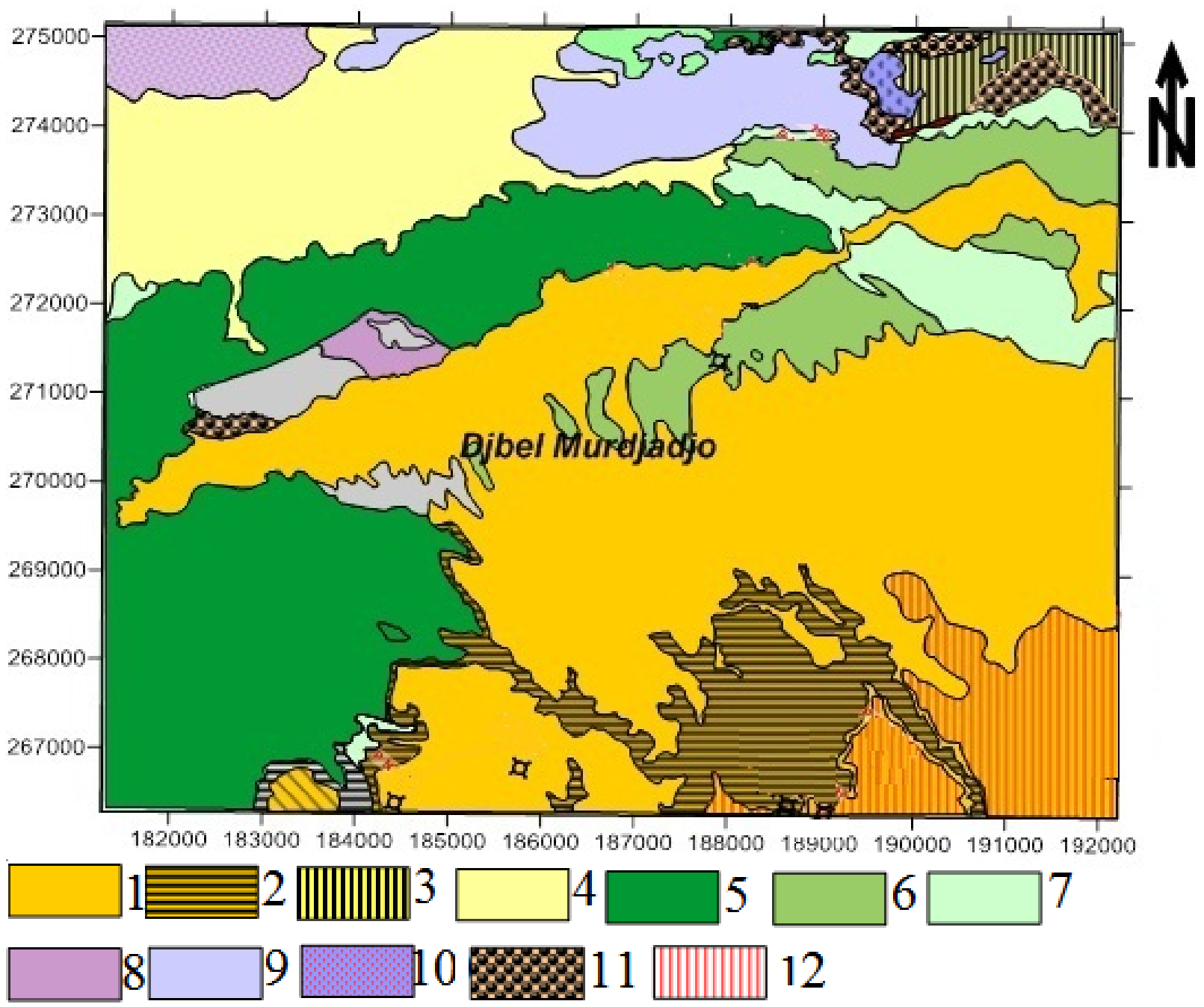

1: Limestone algae, 2 white Marno limestone with or without Tripoli, 3: gray marl, 4 alluvium and scree of gravel slope, 5 Schist and limestone 6: quartzite, 7 limestone dolomitized, 8: calcschists, 9: Limestone disposed in sublithographic benches, 10: Shale and quartzites, 11: Alluvium red and salt spreaders, 12: Scree. [45]

Figure 2. Geological map of the study area in relationship with the Oran Great Sebkha and the southern catchment of Murdjadjo Mountain,

\section{Goals of Work}

Initially, it was done:

- A lithostratigraphic and structural study of the locality of Misserghin.

- A detailed morphological and analytical comparison of successive deeper layers that characterize the soils of the Misserghin region.

- Correlation with other neighboring areas that allow better visualization of the geometrical arrangement of sedimentary processions.

- Quantitative and qualitative chemical analyzes of soil and water in the study area.

- A test a soil analysis Misserghin region.

- A topo-sequential analysis and relations with farming skills and land use possibilities Misserghin.

- A proposal for a Misserghin of hazards map to determine and delineate areas that may be exposed to natural hazards, and to propose measures vis-à-vis these risks protection.

\section{Characteristics of the Main Soil Units Misserghin (Figure 3)}

A. At the foot of Murdjadjo Mountain (soil fersiallitic): Note that the presence of the $\mathrm{C}$ horizon (rocks), Messinian reef limestone.

The formation of the Mekarra [52] presents colluvium soils; near the North Farm Garcia Missereghin red alluvium have a thickness of 50 to $60 \mathrm{~cm}$, below a limestone outcrop crust. The relief and slope are important factors of soil rejuvenation. On slopes, we find that rendzinas, lithosols, colluvium, scree and hard limestone outcrops [1]. 


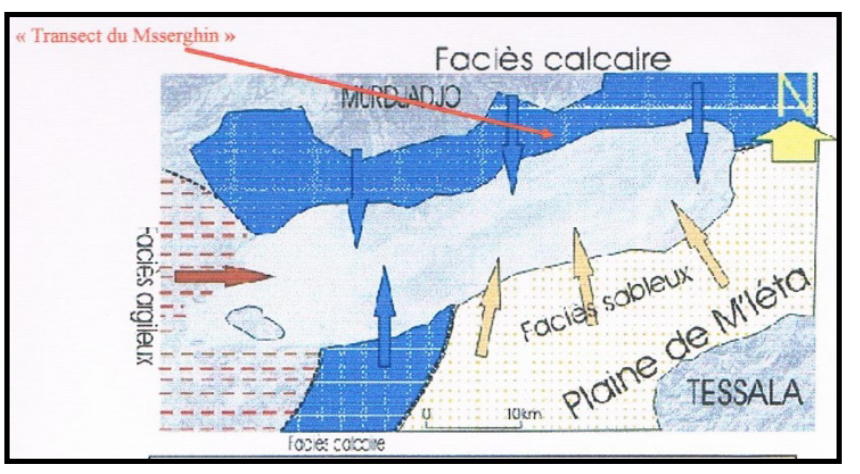

Figure 3. Facies (soils) map of the Oran Great Sebkha [44]

B. In the plain (alluvial soils):

All the plain of Misserghin-Bredeah present alluvial soils with very thick horizon (fluvial sequence) almost all soils of the plain are rubefies (red or terra-rossa soil); terra-rossa: Red clay is a land fill all excavations and limestone fissures, it is a mixture of red clay decalcified from the underlying rock, and detrital complex.

The deposits of the plain are more or less stony deep, finely surface in places, and successive terraces in the top of the plain formed by landing rather than sedimentation. Filling deposits and high depression are under the same index. A Bredeah near the Sebkha, the outcrop of the A horizon is $50 \mathrm{~cm}$. The $\mathrm{C}$ horizon (bedrock) from 4 to $10 \mathrm{~cm}$, the $\mathrm{B}$ horizon is eliminated by the presence of calcareous shell [1].

\section{Relative Importance of Different Units of Soil Misserghin (Figure 4)}

The relative importance of the different soil units was evaluated from the soil map of the Misserghin region. The Misserghin Plain is occupied in its totality by alluvial soils.
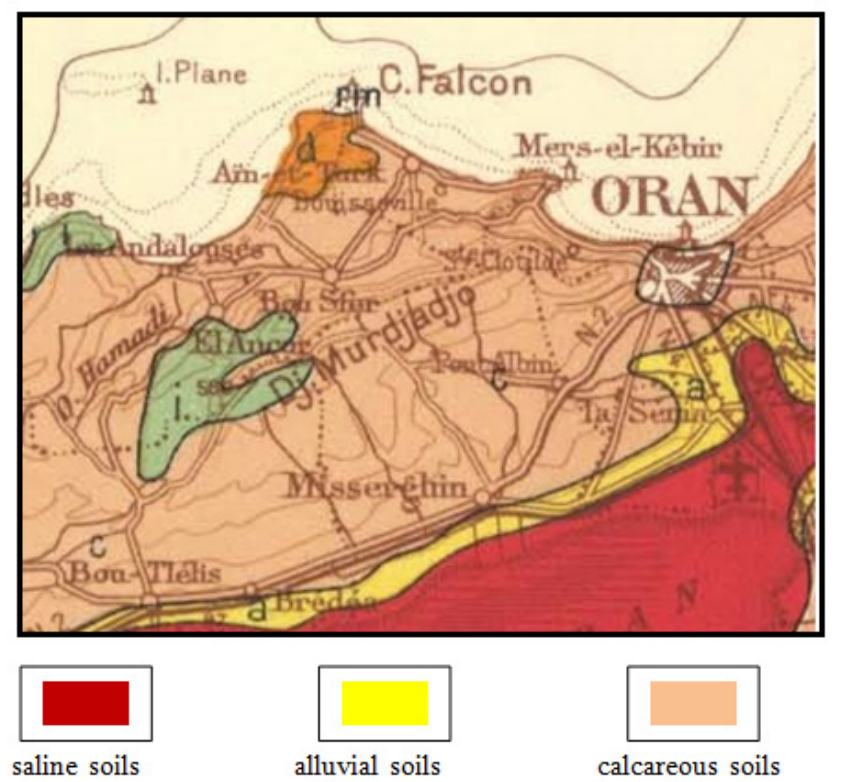

Figure 4. Soil Map of Misserghin region (Durand, 1954) in [7]
These soils are deeper and naturally fertile but as many alluvial soils, fersiallitic soils are moderately deep soils , clay, red, which form on the Hill Murdjadjo and end of saline sodic soils ( soil - salino ) are sandy clay soil gypsum, like the little evolved soils, they occupy the upstream portion of rainwater.

\section{Land Qualities Agrological}

In light soils, eight main stress factors arise for the cultivation of these lands:

\subsection{Effective Depth}

The effective soil depth of this sector is highly variable; moreover, these soils are more and lee thickness. The fersiallitic soils, brown soils and poorly developed soils slightly evolved and affected by the erosive phenomena. This character limits the scope for rooting plants, in particular with regard to shrub and tree crops. Tropical pines (Pin us Caribaea) for their hardiness, are in this respect a relative exception; they grow on shallow soils but growth rates are much lower on these soils on deep soils. In the lowlands, waterlogging is also a barrier to root penetration of certain crops. This constraint had partly been surmounted in ancient times with the construction of balances of $80 \mathrm{~cm}$ to 1 $\mathrm{m}$ high separated by drains. These balances must allow crops to be out of water even in the rainy season.

\subsection{Texture-stony-rock}

The texture and stoniness act as constraints for crops by the existing link between water reserve and texture, the possibilities of rooting plants and by the limits mechanization of land. In addition, the sandy texture of the A2 horizon of podzols is a major obstacle for annual crops.

The textural difference between sand and clay (B and A2 horizons) of podzolic soils fersiallitic trend causes a discontinuity in unfavorable profiles root growth. Finally, excessive stoniness as is the case for some fersiallitic soil on old alluvium may hinder some cultures. The use of mechanical equipment to work the land of hills and glaucophanites schist will face for its part to the presence of rock fill or too abundant stoniness. This is the case in many slightly evolved erosion soils and rejuvenated fersiallitic, washed or not, on schists and glaucophanites. Indeed, it is not recommended because of the increased risk of erosion.

\subsection{Potential Water Reserves}

This region can be confronted with long droughts and potential soil water reserve is a significant adjunct to plant water supply.

On the hills and mountains, this reserve is reduced mainly due to the shallow soil and thus reduced possibilities of plant roots. The evaluation of this subject by the formula (Hallaire, 1968) in [26] gives values between 30 and $70 \mathrm{~mm}$. It is 
therefore not a sufficient stock of water to allow plants to survive long dry season (maximum one month).

On the lower slopes, soils are deeper and more clayey. It is moderately deep fersiallitic soils. Their potential water reserve is higher and between 80 and $150 \mathrm{~mm}$. It allows plants, especially herbaceous plants, green to stay longer (about two months) in the dry season, but it is not enough to spend the dry season.

Finally, in the plain, alluvial soils have an important water reserve. At that reservoir, water is added the contribution of groundwater. Thus, soils remain cool during much of the dry season.

\subsection{Hydromorphy}

Hydromorphy occurs to varying degrees in all the plain soil. This waterlogging is primarily due to the low-lying alluvial zones, the proximity of the water table and the effect of their temporary fluctuations and not to soil permeability. This waterlogging is therefore difficult to fight by drainage, slope drains to be very low.

\subsection{Flood Risks}

Although not directly related to soil characteristics, flood risks are a major constraint agrological in this region. Floods, especially by the currents and the risk of water stagnation they create, destroy ground parts of annual crops are rotting the roots. Their effects on perennial tree crops are less important than annual crops.

\subsection{Deficiencies}

Soil fertility in this region is generally poor to very poor and this is largely due to deficiencies in major and minor soil.

\subsection{Imbalances of Minerals and Toxicity}

The excess of magnesium, salinity, and the risk of aluminum toxicity are the three most pronounced mineral imbalances in soils.

\subsection{Erosion Risks}

In this region in very rugged terrain, the risk of erosion is very strong in the case of tillage. The vast majority of the observed slope of soils is also truncated by soil erosion. (Figure5). At this slope factor must be added soil factor. The fersiallitic soils are indeed very susceptible to erosion and misbehaving clearing can lead very quickly to the creation of ravines.

This map (Figure 5) is made from aster image using the ArcGIS software on the study area. This shows that the land is in a large slope, which sometimes exceeds $25 \%$ that can promote erosion. Especially in the glaze by Murdjadjo against the top of the plain and the slope is strong enough between 11 and $25 \%$ at Sebkha more or less low slope between 0 and $11 \%$.

Finally, risks exist in the floodplains during floods where a freshly plowed field is likely to be taken away.

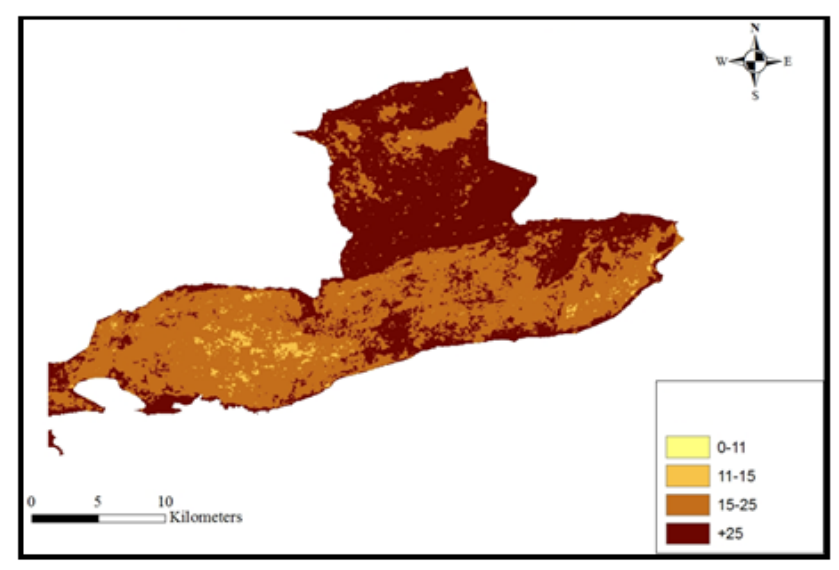

Figure 5. Map of slopes Misserghin region

\section{Proposal for a Hazard Map (Figure 6)}

The mapping of natural hazards is to delineate areas that may be exposed to natural hazards and to enact protective measures overlooked these risks. It was therefore a first technical phase to estimate the probability of occurrence of a given event in a given place, called probability hazard. The hazards are the possibility that a phenomenon, a physical natural manifestation (non-biological) relatively brutal, threatens or affects a given area. It is therefore the estimate of the realization of this process. This concept is important in the study of major risks, it is necessary in the field of regional planning. The evaluation of the hazard (intensity, temporal proximity, frequency) in a given place is without prejudice of any damages (casualties, destruction of infrastructure, environments) or possible economic consequences [56]. The hazard map is made by software map info on geomorphological maps [43], geological map [45] and vegetation map [46]. After the setting of the three cards, it was determined the vagaries of our study area are:

Faults, cliffs, gullies, loss, mass flow and soil salinity.

\section{Ability Cultivation}

At this very diverse natural fertility is the development opportunities of soils studied varied enough. The current under-utilization of rural potential of this area is evident, and although a lack of some experience exists with regard to the introduction of new crops, we can reasonably hope for the future diversification and intensification agriculture and livestock. 


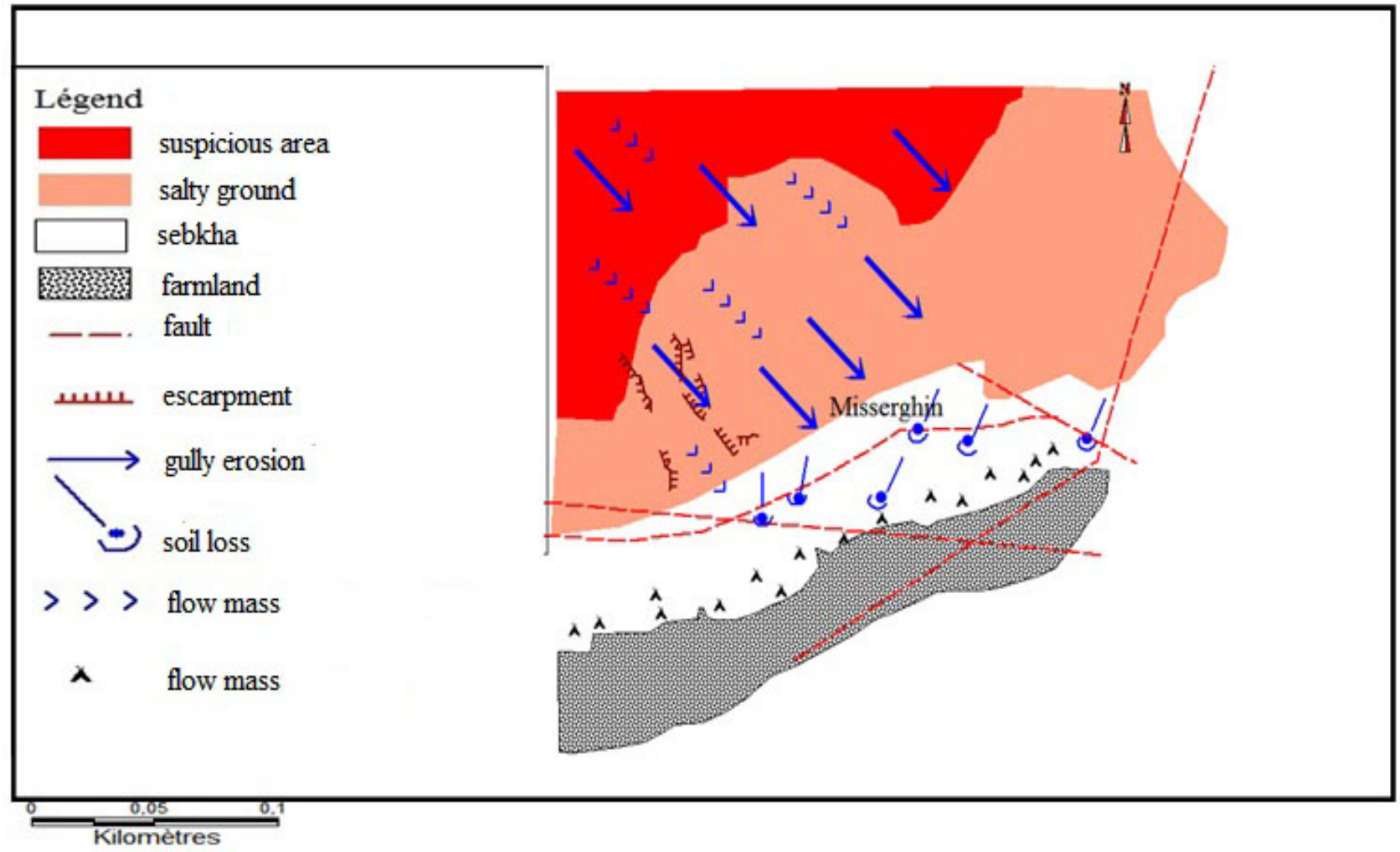

Figure 6. Map of the hazard of Misserghin region

\subsection{Possible Cultures}

\subsubsection{The Dry Annual Crops}

For dry annual crops, means cereal or row crops and food crops that are produced in mid drained without water intake. These crops are currently very small extent with the exception of food crops:

- The olives, grains: They require deep soils and balanced texture.

\subsubsection{Artificial Pastures}

By artificial pastures, grazing means entirely made after plowing and fertilizing. As annual crops, it's necessary to mechanically install good quality land. In addition to the lowland plains, we can use the down slope colluvial soils. The current extension of this type of pasture remains extremely limited. These pastures should be extended as an auxiliary and safety during the dry season.

\subsubsection{Improved Pasture}

Improved pastures are mainly pasture has been a clearing of trees and shrubs, possibly accompanied by a light tillage and legume seeds of seedlings. It doesn't get these pastures in a complete change of flora, but a marked increase in forage potential. This use seems to be one of the main skills of medium quality land to poor hills of basic rocks or region acids.

\subsubsection{Shrub and Tree Crops}

The plantations of fruit crops have so far only a small development in the sector. The favorable soil for this type of culture is deep soils, well drained and fresh. Alluvial soils are certainly the most favorable terrain. Tests may, however, be conducted on fersiallitic soils on ancient alluvial terraces or position -slope on brown soils or soils fersiallitic. The flood risk is smaller for these crops than for annual crops. They are not, however, neglecting especially asphyxiation that can cause these floods in leaves after significant alluvial deposits.

\subsection{Classification of Land Misserghin}

The lands of this region have been classified into three major categories [43].

\subsubsection{The Land of Good Quality Agrological}

These lands have little physicochemical or morphodynamic constraints and may give important productions. In this category were selected deep soil well drained and with favorable chemical properties.

\subsubsection{Agrological Poor Quality Land}

These lands have one or more unfavorable characteristics can be developed in a modest way, with minimal investment. These possibilities of enhancing focus on the creation of pastures or forests, these are fersiallitic soils.

\subsubsection{Agrological very Poor Quality Land to Zero}

These lands have one or more adverse edaphic characters and do not seem likely to be based, in the present state of our 
knowledge on economic development (saline-sodic soils). For each category, different cultural skills are offered. These should be accompanied by improvements in the quality of soil.

\section{Soil Fertility and Use Opportunities}

Misserghin area and the Oran Great Sebkha were very fertile agricultural areas during the colonial period, but this agricultural activity consists of only a few food crops are located near the Sebkha.

\section{Adaptation of Cultures}

Misserghin area and the Oran Great Sebkha were very fertile agricultural areas during the colonial period, but currently this activity involves only a few food crops located near the Sebkha.

\section{Operating Results of a Crop Misserghin}

Farmers are concerned;

- The type of crop to be implemented, because of the salinity and water scarcity.

- The birth of an irrigation system, but we must work for the safety and protection against the rise of salt water.

- The depletion of groundwater.

- The expansion of the city towards the agricultural lands that poses a real problem.

\section{Conclusions}

Farmland, like all rural areas in Algeria today the place is very deep changes and transformations are needed.

Misserghin commune is located in the western Algerian Tell, just in the foothills of Jebel Murdjadjo and at the northern margin of the Great Sebkha of Oran. In our study, we relied on their physical environment, their soil and their agricultural capability, and in order to show the relationship between these different aspects. The physical environment has allowed us to study climate framework, hydrogeological, geological, and geomorphological and vegetation Misserghin.

Then we get results as follows;

i. On Climate Plan: Misserghin is assigned a semi-arid climate, despite its proximity to the sea; it has revealed the existence of two periods; in October-April rainy and dry in June-September.

ii. On the hydrogeological: from the work of Hassani [23] and Moussa [40], the town of Misserghin has generally superposition of two plies; on deep fresh water and the other shallower brine. The groundwater flow is from the Mount Murdjadjo to Sebkha.

iii. On Geologically: we relied on topo-sequential analysis and from the work of Moussa [44], we worked on five profiles from the top of Murdjadjo to downstream (Sebkha), we found each time the change of the thickness of the floor and the lateral changes of the mineralogical and chemical parameters.

iv. On The geomorphology: The presence of a ridge separating the Oran watershed Sebkha itself that disappears at the eastern part of the Sebkha, this being due to a collapse of Misserghin-Ain panel Beida, a plateau top, glazes, losses, cradles valleys, river systems and plateaus at different altitudes.

v. The vegetation is distributed differently depending on soil quality, altitude and proximity to the Sebkha. In the third chapter, we are interested in the study of soil and using the soil map of Algeria, we defined three soil types that are represented in our study area [1].

vi. The Fersiallitic soil: at the foot of Murdjadjo mountain, which are agrological poor quality land, moderately deep, these soils have one or more adverse characters that can be developed in a modest way, they occupy the downstream part of the Mountain in question and that by installing a dense forest on a relatively steep slope.

vii. The Alluvial soils: occupying the plain Misserghin on a medium altitude slopes. This is good quality land agrological, deeper, naturally fertile, with favorable chemical properties (nitrogen: 2.5 to $30 / 00$, phosphate $0.80 / 00$ ), we find it as diversified crop vines, cereals, citrus, fruit trees etc.

viii. The Saline sodic soils (or soil-salino): occupying the downstream part of the catchment area (in the proximity of the Sebkha SS) are agrological very poor quality land to zero, these soils have one or more extremely unfavorable edaphic characters These lands are occupied by salt-tolerant vegetation.

In the last chapter, we conducted the study of fertility and therefore the usability of these soils should be considered. We identified eight factors controlling the cultivation of land Misserghin. Then we proposed a region of hazards map to determine and delineate areas that may be exposed to natural hazards.

\section{REFERENCES}

[1] F. Adda. Caracterisation geologique, chimique et pédologique du versant nord de la Grande Sebkha d'Oran au Mio-Plio-Quaternaire (ex :Brédéah-Misserghine), Mém. Ing. D'état, Univ Oran, 2000. 
[2] Agence Nationale Des Ressources Hydrauliques. Carte piézométrique du secteur de Bou Tlélis-Misserghin, document interne (inédit). 1986.

[3] R. Ameur. Biochronologie des formations continentales du Néogène et du Quaternaire de l'Oranie : Contribution des Micromammifères, Thèse 3ème cycle, Oran, 77p, 1979.

[4] [4]R. Anderson. Geology in the Coastal Atlas of Western Algeria, Mem. Geol. Soc. Amer, New-York, 450p, 1936.

[5] C. Arambourg. Les poisons fossiles d'Oran, Matér. Carte geol. Algérie, Alger, (1), 6, 86 pl., 298 p. 1927.

[6] C. Arambourg. contribution à l'étude des formations laguno-lacustres des environs d'Oran. Bull. Soc. Hist. nat. afr. Nord, Vol.41, 20-29. 1950.

[7] K. Bahi. Contribution à l'Etude phytoécologique des zones Humides de la région d'Oran, mémoire. Magister, en biologie, 104p, Univ. Oran, 2012.

[8] R. Baudrimont, C. Degiovanni. Les diatomées marines du Miocène supérieur de l'Oranais (Algérie) et leur contexte géologique, Bull. Soc. Hist. d'Afr. Nord, Alger, t. 65, fasc. 1 et 2, pp. 35-66, 3 pl. photo h. texte, 5 fig. 1974.

[9] R. baudrimont, C. Degiovanni. Interprétation paléoécologique des diatomites du Miocène supérieur de l'Algérie occidentale. C.R. Acad. Sci.Paris, 278, p. 1337-1340.1976.

[10] G. BARNAUD, FUSTECE. Conserver les zones Humides : pourquoi ? Comment? Ed Quae. 296p. 2007.

[11] H. Bellon. Séries magmatiques néogènes et quaternaires du pourtour de la Méditerranée occidentale, comparés dans leur cadre géochronologique. Implications géodynamiques. Thèse Es-Sciences, Paris, 367p.1976.

[12] H. BELlON, J. Hernandez. Chronologie et évolution chimique des laves du Rif oriental (Maroc) et du Tell oranais (Algérie). 4ème R.A.S.T., Paris, p.44.1976.

[13] A. Berrabeh. reconsidérations biostratigraphiques des dépôts d'âge miocène inférieur (au sens d'A. PERRODON, 1957) du bassin du Bas Chélif. Mém. Ing. Etat, Univ. Oran, 55 p., 22 fig. 1998.

[14] G. Betier. Feuille Oran-Nord de la carte au 1/60 000è. Bull. serv. Carte. géol., Algerie.1941.

[15] H. CHAMLEY, C. robert. Sédimentation argileuse au Tertiaire supérieur dans le domaine méditerranéen. Géol. Méditer., t. VII, $n^{\circ} 1$, pp. 25-34.1980.

[16] M. Chaumon T, C. Paquin. Notice explicative de la Carte pluviométrique de l'Algérie au 1/50 000. Publ. Soc. Hist. Nat Afr. Nord. 24 p. Alger. 1971.

[17] D. COULIBALY. Reconstitution climatique du littoral oranais, depuis le Miocène à l'Actuel : Etude des argiles de la coupe de référence du ravin de la vierge. Misserghin-Sebkha d'Oran.2006.

[18] M. Dalloni. Le Miocène supérieur dans l'Ouest de l'Algérie : couches à Hipparion de la Tafna. C. R. Acad. Sci. Paris, t. 16, pp. 428-641.1915.

[19] F. Doumergue \&e. Ficheur. Notice de la Carte géologique d'Oran. Bull. Soc. Geog et archeo, Oran, t.XXVIII, fasc. CXVI, p 1-32. 1908.
[20] B. FENET. Recherches sur l'alpinisation de la bordure septentrionale du bouclier africain à partir de l'étude d'un élément de l'Orogène nord-maghrébin : les Monts du Djebel Tessala et les Massifs du littoral oranais. Thèse Sciences, Nice, 301p. 1975.

[21] Y. GOURINARD. Le littoral oranais (mouvements verticaux et anomalies gravimétriques). Publ. XIXème Congrès géol. Int, Alger, Monographies régionales 1ère série, $\mathrm{N}^{\circ} 22,63 \mathrm{p}$. 1952.

[22] Y. GOURINARD. Recherches sur la géologie du littoral oranais. Publ. Serv. Carte Géol. Algérie, nouv. Sér., 6, 111 p. 1958.

[23] M. I. HASSANI. Hydrogéologie d'un bassin endoréique semi-aride, le bassin versant de la Grande Sebkha d'Oran (Algérie).Thèse. 3ème cycle,Univ de Grenoble, 304 p., 128 fig., 65 tab. Nord, Paris (16-17 Décembre 1997), p.89. 1987.

[24] R. LAFFITE. Sur l'existence du Calabrien dans la région oranaise. C.R. Acad. Sci., Paris, pp 217-219.1950.

[25] J. Magne, Cl. Tempere. Micropaléontologie de deux bassins néogènes algériens : le Chélif et le Hodna. Application aux recherches du pétrole. 9èmeCongr. Géol. Int. Alger, Section XIV, Fasc. XVI, pp. 92-102.1952.

[26] L. MARC. Carte des sols et carte d'aptitude culturale et forestière institut français de recherche scientifique pour le développement en coopération de PARIS. 1985.

[27] D. MEGHERBI. Etude lithostratigraphique et sédimentologique de la série mio-plio-quaternaire de la région d'El Kerma (Oran Sud-Est). Mém. Ing. Etat. 33 p. 24 fig. Pl-photo 4. 2013.

[28] A. MEKKI. Etude géologique de la Grande Sebkha d'Oran ; cas du secteur d'El Amria-Bou Tlélis (Stratigraphie, Sédimentologie, Pédologie), Mém. Ing. Etat, Univ. Oran, 123 p, 36 fig, 11 tabl.2002.

[29] G. Millot. Géologie des argiles. Masson, Paris VII, 197 p.1964.

[30] P. Moissette. Faunes de bryozoaires du Messinien d'Algérie occidentale. Thèse Es-Science, Lyon, 392 p., 22 fig., 6 tabl., 31 pl. photo. 1987.

[31] K. MOUSSA, L. Belkébir. R, B. Mansour, M. Bessedik. Dynamique et évolution de la marge sud du bassin du Chélif (Algérie) vers une plate-forme carbonatée (Miocène supérieur). Approche sédimentologique et stratigraphie séquentielle. Géologie Méditerranéenne, Marseille, tome XXI, n॰3-4, pp.131-132.1994.

[32] K. MOUSSA. Le Pliocène marin du bassin du Bas Chélif: Aspects stratigraphiques et paléogéographiques, Xème Séminaire National des Sciences de la Terre, Alger Hotel El-Aurassi (25-28 Mars 1995), p. 25.1995.

[33] K. MOUSSA, J. Neurdin-Trescartes, L. Belkébir. Proposition d'une nouvelle méthode d'agencement et de dénomination des formations sédimentaires miocènes du Bassin du Bas Chélif (Oranie, Algérie). IIIème Séminaire de la géologie pétrolière, Boumerdès. (26-27 Novembre 1997). pp. 47-48. 1997

[34] K. MOUSSA, J. Neurdin-Trescartes, L. Belkébir, M. Bessedik, 
B. Mansour. Stratigraphie séquentielle d'un bassin intramontagneux (Bassin du Chélif, Oranie, Algérie): implications paléogéographiques et géodynamiques. Les marges téthysiennes d'Afrique du Nord, Paris (16-17 Décembre 1997), p.89. 1997.

[35] K. MOUSSA, J. Neurdin-Trescartes, M BESSEDIK, L. Belkébir. Sequential agencement modalities in the Miocene sedimentary bodies from the intramontainous Chelif, basin (Oranie): An integrate stratigraphic approach. 15th International Sedimentological Congress, Alicante (April 12-17 Les marges téthysiennes d'Afrique du Nord, Paris (16-17 Décembre 1998), p.566. 1998.

[36] K. MOUSSA, J. Neurdin-Trescartes, F. Drief. Application des méthodes aérospatiales aux formations miocènes du bassin du Chélif(Oranie-Algérie). Colloque international, l'observation spatiale : un outil pour l'étude du bassin méditerranéen, Tunis 23-27 Novembre.1998.

[37] K. MOUSSA. Quelques aspects géomorphologiques, hydrogéologiques, biologiques et chimiques de la Sebkha d'Oran; implications environnementales. Séminaire national sur l'Agronomie et l'Hydraulique en zones arides et semi-arides, Ouargla 8, 9 et 10 Novembre. 1999.

[38] K. MOUSSA. Quelques aspects géologiques, géomorphologiques, hydrogéologiques, biologiques et chimiques de la Sebkha d'Oran (Algérie) ; implications environnementales. Fifth International Conference on the Geology of the Arab World (GAW-5), February 2000, Cairo-university. 2000.

[39] K. MOUSSA. Histoire d'un bassin sédimentaire endoréique : la sebkha d'Oran, 4ème Séminaire de Géologie pétrolière, C.R.D, Boumerdès 13-15 Novembre 2000b.

[40] K. moussa. Une mise au point stratigraphique de la série sédimentaire miocène du Djebel Murdjadjo (marge nord du bassin du Bas Chélif, Oranie), 1er sém. Nat. de stratig. Orgm, Alger, pp. 66-67.2000.

[41] K. MOUSSA. La recherche des ressources hydriques : Méthodologie systématique intégrant les méthodes des sciences de la terre et de la vie, cas de l'étude de la Sebkha d'Oran, 11èmeSémin. Nat. Sci. Terre, p. 67. Tlemcen 28-30 octobre. (2001).

[42] K. Moussa. Carte géomorphologique de la Grande Sebkha d'Oran (Algérie) : Description et interprétation dynamique. Bulletin de l'ORGM, Alger, 1er janvier 2006, p. Vol. 17, n1. pp. 47-62, 5 fig., 2006.

[43] K. MOUSSA et D. COLIBALY. Reconstitution climatique (du Miocène à l'Actuel) du littoral oranais, à travers l'étude des argiles caractéristiques du transect Misserghin-Sebkha d'Oran. XIIème Séminaire National des Sciences de la Terre, université d'Oran-Es-Sénia, p. 37.2006.
[44] K. MOUSSA. Etude d'une Sebkha : la Sebkha d'Oran (Ouest algérien). Thèse Es-Sciences, univ. Oran., 205 p., 153 fig., 5 tabl., 12 pl. ph. h. t. (Oran, Algérie). 2007.

[45] K. MOUSSA. Esquisse géologique de la Grande Sebkha d'Oran, Bulletin du service géologique national, Volume 22, n03. 9p. 2011.

[46] K. MOUSSA. Contribution to the study of the vegetation of the Oran's Great Sabkha basin (west Algeria); characterization and cartography. Scholarly Journal of Agricultural Science Vol. 4(5), pp. 273-279 May, 2014 Available online at http:// www.scholarly-journals.com/SJAS ISSN 2276-7118 @ 2014 Scholarly-Journals. 2014.

[47] K. MOUSSA, N. BOUALLA. La sédimentation Plio-Quaternaire d'Oran (Ouest Algérie): aspects stratigraphiques et sédimentologiques, Actes de la sixième rencontre de quaternairistesmarocains (RQM6). 18-23. 2014.

[48] J. NEURDIN-TRESCARTES. Le remplissage sédimentaire du bassin néogène du Chélif, modèle de référence de bassins intramontagneux. Thèse. Doct. Etat, Univ. Pau \& des de l'Amour, 2t. 605P.1992.

[49] A. PERRODON. Etude géologique des bassins néogènes sublittoraux de l'Algérie occidentale. Thèse et Bull,Serv. Carte Algérie, no 12, 323 p., 95 fig., 4 pl. h. t. 8 pl. photo.1957.

[50] P. QUEZEL. Ecologie et biogéographie des forêts du bassin méditerranéen. Institut méditerranéen d'écologie et paléoécologie Univ. Aix - Marseille III. 571p. 2003.

[51] F. SAAD. Corrélation et essai de reconstitution paléogéographique de la série miocène de la partie occidentale du bassin du Bas Chélif (massifs littoraux-Sebkhad'Oran-Tessala). Mémoire d'ingénieur, Université d'Oran, p. 63, fig. 45, 2000.

[52] G. Thomas. Géodynamique d'un bassin intramontagneux. Le Bassin du Bas Chélif occidental (Algérie) durant le Mio-Plio-Quaternaire. Thèse Es-Sciences, Pau, 594 p., 162 fig., 32 tabl. 3 pl. h.t. 1985 .

[53] J. Trichet. étude des faciès d'une dune gypseuse (Sud d'Oran, Algérie), Bull. soc. Géol. De France, (7), IX, p 865-875, 6 fig. 2 texte-planche. 1967.

[54] L. VILLE. Notice géologique et minéralogique sur la partie occidentale de la province d'Oran. Bull. Soc. Géol. France, (2), 9, 363-380.1852.

[55] L. VILLE. Notice minéralogique sur les provinces d'Oran et d'Alger. Imprimerie Impériale. Paris, 349p. 1857.

[56] M.XAVIER, C.PATRICE. (Aléas), management du risque pour un développement durable, Dunod coll. « Technique et ingénierie». 2009. 